\title{
Application of Data and Management in Engineering Sector
}

\author{
Chet Narayan Subedi ${ }^{1 *}$
}

*1 Faculty member, Prithvi Narayan Campus Faculty of Management (Pokhara), affiliated to Tribhuvan University, Nepal

*Corresponding Author: -

\begin{abstract}
: -
In this $21^{\text {st }}$ century, the engineering complexity has increased drastically. Almost all the engineering problems are interdisciplinary, that means, the experts from different backgrounds (for instance, engineering, management, data analytics, etc.) are essential to solve any real time problems. The history is very affluent with many examples of project failures due to poor or inappropriate perspective. The project failures might be construction failure, start-up failure, business failure, management failure, etc. However, on the other side, there are many successful case examples which are implemented with effective management skills. Some examples include banishing darkness from Himalayan nation 'Nepal', travel management among millions of sports enthusiasts in 2012 London Olympics, fund raising in 2008 presidential campaign in United States of America, etc. This paper focuses on real time problems faced by most of the African countries with their isolation in online global business trend due to poor management skills. Some case examples of good management skills are presented at the end of this paper.
\end{abstract}

Index Terms: - Engineering, Management, Managerial skills, E-commerce, Global isolation, online business

\section{(c) $\$(1)$}




\section{I.INTRODUCTION}

Management is the administration of any organization, whether it is a business, a not-for- profit organization, or government body [Retrieved from Wikipedia]. It includes the activities of setting the strategy of an organization and coordinating the efforts of its employees (or of volunteers) to accomplish its objectives through the application of available resources, such as financial, natural, technological, and human resources. Different persons have defined management in their own terms. Some are highlighted below:

- According to Henri Fayol, "to manage is to forecast and to plan, to organize, to command, to co-ordinate and to control."

- Fredmund Malik defines it as "the transformation of resources into utility."

- Ghislain Deslandes defines it as "a vulnerable force, under pressure to achieve results and endowed with the triple power of constraint, imitation and imagination, operating on subjective, interpersonal, institutional and environmental levels."

- Henry Mintzberg defines, "Management is, above all, a practice where art, science and craft meet."

- Paul Hawken explains, "Good management is the art of making problems so interesting and their solutions so constructive that everyone wants to get to work and deal with them."

Concepts of management have evolved very earlier and its utility have flourished at a greater extent in today's world. Different theories have been explained by different individuals. Among them Peter Drucker is known as the father of Management Theory.

Peter Drucker (1909-2005) saw the basic task of management as twofold: marketing and innovation. Nevertheless, innovation is also linked to marketing (product innovation is a central strategic marketing issue). Peter Drucker identifies marketing as a key essence for business success, but management and marketing are generally understood as two different branches of business administration knowledge.

Social scientists study management as an academic discipline, investigating areas such as social organization and organizational leadership. Some people study management at colleges or universities; major degrees in management include the Bachelor of Commerce (B.Com.) and Master of Business Administration (MBA.) and, for the public sector, the Master of Public Administration (MPA) degree. Individuals who aim to become management specialists or experts, management researchers, or professors may complete the Doctor of Management (DM), the Doctor of Business Administration (DBA), or the PhD in Business Administration or Management.

Management can be explained as a process or an activity or a discipline or an art or a profession. It bears a crucial utility at every walks of peoples' life whether in terms of personal or profession mean. Various areas like administration, business, science, engineering and the society have a greater application of Management which aims to secure maximum outputs with minimum efforts \& resources, to increase the efficiency of factors of production by reducing spoilage, wastages and breakage of all kinds which is essential for the growth \& prosperity, to ensure maximum prosperity and functioning of the organization to enable the human betterment \& social justice and many more.

The use of management in the science and technological world of $21^{\text {st }}$ century bears a greater importance since the better management results in better results enabling better efficiency. Talking about the technological world the study of interlinkage between Management and Science and technology i.e. Engineering comes at the front line. Amid plenty of examples of coherence between engineering and management, this paper talks about specific reasons how poor management skills led to isolation of most of the African countries from global trend of online business.

\section{Problem Statement}

Internet has become a part of our life. At the moment, millions of people are connected to the internet. It has entirely changed the way we play, work, interact with each other, do business and even changed the way we live.

In this $21^{\text {st }}$ century, online business is possible with the presence of the internet. Online business has hit everywhere in this globalized modern world. Small to large company has taken a lot of benefits through online business. Almost all the developed nations are doing online business as it is cost savings, global access (24 hours a day/7 days a week), faster delivery of products, increased professionalism, less paper waste, has no border, environmental friendly, easy to track, easier and faster financial transaction, and we can manage our business from anywhere in the world. Moreover, online business has made customer easier for shopping items. As they can shop anywhere and anytime, save time, search for online reviews, search for the best deals, avoid compulsive purchases, no need to face crowds and queues, save cost of parking charges and petrol, and can easily access to variety of products.

According to Rahayu and Day (2015), e-commerce changed the way we sell, purchase and way of dealing with suppliers and customers and even make changes in business perspective. The author Rahayu and Day (2015) says to survive in this new economic business world; every company (organization) should adopt this new technology (e-commerce). Those who do not follow this practice and philosophy will be left behind by e-commerce adopters.

At the moment, entire globe is competing online. Every company gives priority to online business particularly in developed nation such as Australia, USA, China, Japan and so on. Africa is a poor developing continent. E-commerce has potential to enhance to find avenues for development. It will play a significant role to uplift the life style of the African people. Despite having vital advantages, the trend of online business is still lacking in most of the African countries (especially in Sub-Saharan countries). The people from Africa are following the trend of offline business.

According to De-Roy (2010) people that are getting Internet service is less than one-third of the African population. Access to the Internet is one of the major problems in Africa. Also the cost of the Internet is high; infrastructures 
development is limited in these regions, and people are lacking knowledge regarding the use of Internet. Some of the regions are well equipped with infrastructure and integration issues are fixed but due to illiteracy people could not take part directly on e-commerce as it require writing and reading skills (Ndonga, 2012). According to Ndonga (2012), people loose trust on online shopping because of online fraud and security measures. Therefore, they prefer to pay on cash. Fragmented market is the next barrier for e- commerce in Africa. Africa has a diverse population with different politics, cultures, and economics. Dealing with taxes and tariffs, cross border payments and meeting several country legal requirements makes e-commerce difficult to run within and outside their own country.

Moreover, delivery system and transportation is not well set up to run e-Commerce industry. Most of the African roads are not paved, and the topography (terrain) is difficult to travel that creates barriers for delivery options. According to Ndonga (2012), 620 million Africans are out of reach to electricity that slaps e-Commerce industry. Non-functioning postal system of Africa is the other challenges to operate e-Commerce (online business).

\section{III.Research Objectives And Questions}

This research paper targets to answer the question of:

$>$ What are the causes behind isolation of Africa from global trend of online business?

$>$ How people from Africa can be benefitted from online business (e-commerce)?

\section{Objectives of the paper are:}

$>$ To determine how significant online business is for African people.

$>$ To explore the importance of an Internet in human life.

$>$ To add trust on online business.

$>$ To enhance the thinking of African people regarding online business.

$>$ To describe the flexible of online business for customer services.

$>$ To implement good management skills to meet above listed objectives.

\section{IV.Conceptual Framework of E-Commerce}

\section{A. E-commerce}

According to Ndonga (2012), e-commerce is evolved in mid-1990. It involves business to business transactions, business to consumer, and business process. E-commerce is defined as the exchange of transaction and business communication through internet technologies (Ndonga, 2012). As per Ewelukwa (2011), e-commerce is the buying and selling of products, information, and services through the computer networks using Internet. The author also defined ecommerce is a platform for doing business electronically that is based upon electronic processing and transmission of information (data) that includes sound, text and video. It incorporates many activities such as online delivery of digital content, electronic trading of goods and services, electronic share trading, commercial auctions, electronic fund transfers, collaborative design and engineering, public procurement, online sourcing, after-sales service, and direct consumer marketing. In addition, it includes products (specialized medical equipment and consumer goods) and services (financial and legal services, information services), traditional activities such as education, healthcare and new activities such as virtual malls (Ewelukwa, 2011).

\section{B. Ecommerce in developing countries}

Online business (e-commerce) in developing countries faces more difficulties as compared to developed countries (Molla and Licker, 2005). At the moment, developed countries are well ahead in e-commerce as they are successful in construction of relatively accessible, well- developed and affordable infrastructure, while most of the developing countries lack such infrastructure, thus ecommerce adoption has been restricted. Insufficient information and communication technology (ICT) also limit ecommerce awareness. In addition, lacking of trust over ecommerce makes adoption tougher (Molla and Licker, 2005).

The practice of dealing with non-cash payments, doing business electronically, electronic- based inter and intra business relations are all essential in e-commerce that seems not common in developing countries. Thus, according to Molla and Licker (2005), to develop such practices changes in product characteristics, organizational structure and business culture are necessary. From the case study of Libya, the author El-Fitouri (2015) say that Libyan companies are excited to take benefits from e-commerce, but there are some obstacles to be considered from technological, human, legal and organizational that makes the online business difficult to implement.

According to Alyoubi (2015), there is huge potential of e-commerce in developing countries. E-commerce could upgrade their social and economic development, lower the operating costs of business, lead to gains in commercial productivity, and increase the level of domestic integration with international markets. However, despite having potential many researchers who have tried to find out the benefits from e-commerce in developing countries were disappointed, as developing countries face a lot of barriers in commencing e-commerce (Alyoubi, 2015).

\section{E-commerce in Africa}

E-commerce in Africa is not fully developed according to current standards i.e. second wave of e-commerce (Ndonga, 2012). There is a digital divide that comes as barriers to e-commerce in Africa. According to Ndonga (2012), digital divide includes the divergence of internet access between industrialized and developing societies, inequality of access to the internet, the unequal distribution of computers, fax machine, and internet connections, gap between those who do 
and do not have access to the internet and computers and so on.

Digital divide exists between Africa and the developed countries. Ndonga (2012) says telephone lines in developed world are fairly distributed in each region whereas in developing nations lines are only focused in large cities. At the moment, telephone services have dramatically changed with the entry of smart phone. However, this is not enough to complete the bridge of digital divide.

\section{Barriers for e-commerce in Africa}

As per Ndonga (2012), inadequate ICT infrastructure is one the major obstacles to implement e-commerce in Africa. African States lack fund for ICT projects. It has been estimated that Sub-Saharan Africa would take US\$6.6 billion annually for these new technologies which is extremely high. The other problem is internet technologies. Most of the people in Africa use internet that has bandwidth constraints, thus the connection is slow and inefficient. In addition, the costs of the internet is expensive, thus, this service is limited to poor people. The author Ndonga (2012) says that Africa has lowest amount of internet users (12.8 users per 100 inhabitants).

The other factor that appears as barrier is lack of ICT knowledge in African people. Most of the people don't know how to use computers and the internet. According to Ndonga (2012), culture attitudes played a role in preventing ICT literacy. Sub-Saharan region people trust in face-to-face transacting and those people take electronic medium of exchange as unfriendly and rude.

The next obstacle for e-commerce is online fraud and other cybercrimes in Africa that prevent people to enter into the ecommerce. Due to absence of sound legal and regulatory environment for e-commerce, buyers and sellers do not prefer business over the internet. The impact of M- commerce in Africa also denies the way of e-commerce (Ndonga, 2012). Many people use mobile technology for transaction. In Kenya, they used M-Pesa and in South Africa, WIZZIT. This technology allows them to transfer and withdraw cash from ATM, pay certain bills like school fees, utility bills etc. Currently this service partnered with Western Union that allows client from forty-six countries to send money directly to the account holder. Finally, vast geography, nascent markets, the distance between retailers, consumers and upstream suppliers and the poorly developed infrastructure (e.g., Road) also appears as challenges to commence e- commerce in Africa.

\section{Data Analytics in Management}

Data analytics refers to the processes which enable us to transform the data into information and information into insights to improve the existing world. It is the process of exploring, cleaning, transforming and modeling the data to derive at useful conclusions and support decision-making.

It has spread itself across various domains such as policy making, security, transportation, fraud and risk detection, risk management, delivery logistics, healthcare management, city planning, internet and web search, digital advertisement, etc. The best example where data analytics proved to be a boon and to which we can relate easily is during the travel management at the London Olympics. There was a need for handling over 18 million journeys. The train operators made use of data analytics, predicted the number of people going to travel and ensured that large number of journeys went smoothly. According to Peter Drucker, "What gets measured gets managed". Also, without data, one can only have hypothesis and opinion. Thus, data analytics is a powerful process to measure any situation, take a well-informed data driver decision and manage scenarios effectively.

\section{Kul Man Ghising, The National Hero of Nepal}

The Himalayan nation 'Nepal' was into cruel load shedding for decades. The people were deprived of energy for almost 16 hours a day, despite having the potential to harness enormous amount of energy. Amid this bleak situation, Kulman Ghising (unarguably the national hero) was appointed as the director of Nepal electricity authority (NEA). Fortunately, people witnessed something that was considered next to impossible few years back. His immense managerial skills because vital to eliminate load shedding from almost all the residential areas of Nepal. This used to be the subject of mockery if someone says about elimination of load shedding few years back.

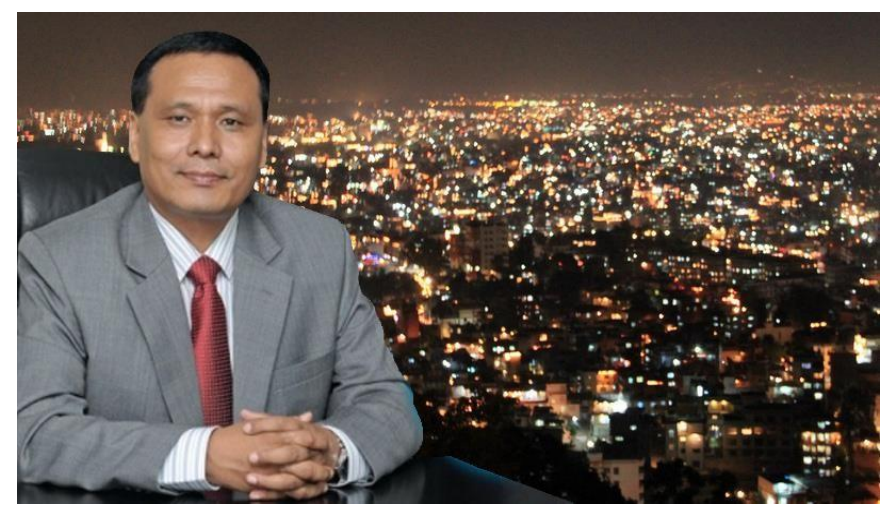

Fig. 1. Kul Man Ghising, and night view of Kathmandu valley on background (Figure courtesy: http://www.tamangvoice.com/2018/05/kulman-ghising-hero-of-the-nation/kulman- ghising_uuyfo4akk4/) 


\section{Good Leader Feels Data}

Needless to say, the society today has become data driven. A/ B testing is one of many tests that is very popular in web analytics. It is a random experiment done with two variants A \& B. Obama, during his presidential campaign in 2007 2008 , used A/B testing to optimize his website design. It is reported that the campaign raised millions of dollars, thanks to A/B testing method.

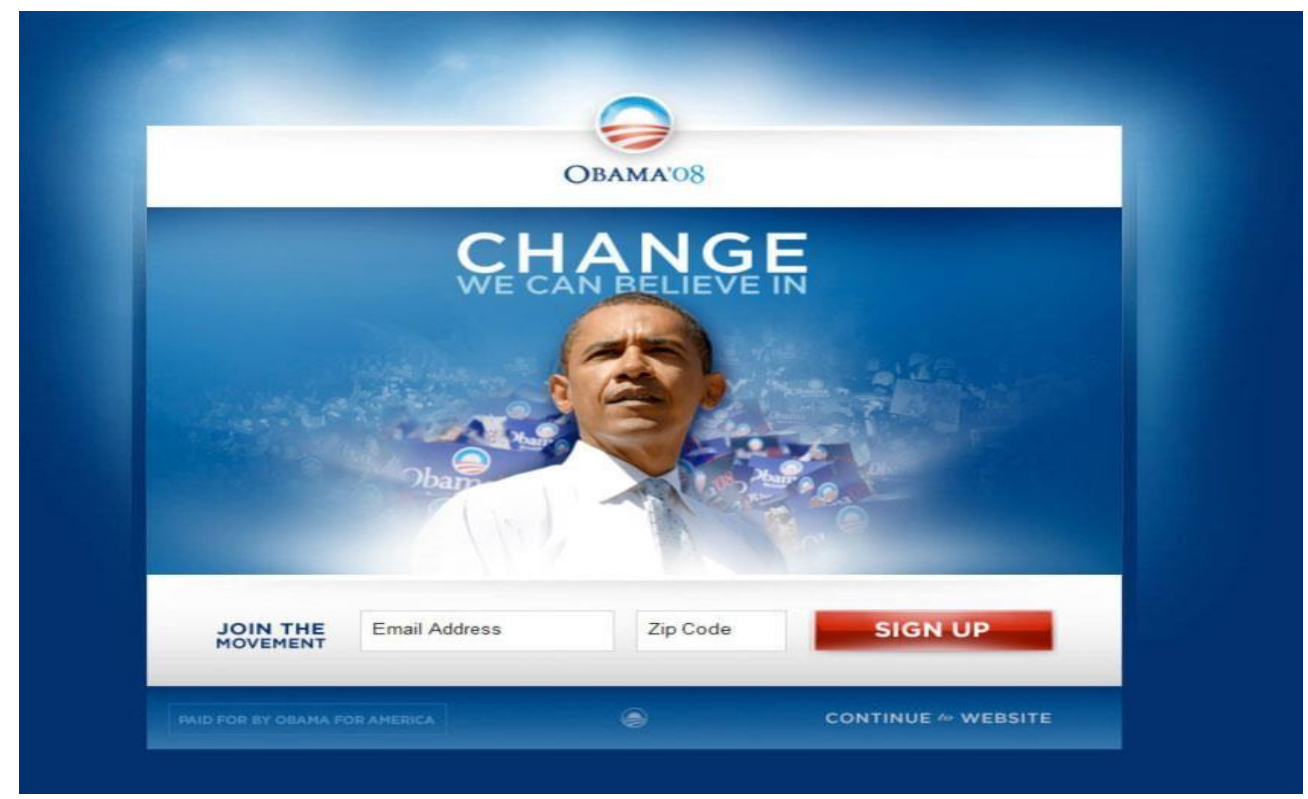

Fig. 2. Website used in 2008 Obama campaign. This was the result from A/B testing. (Figure courtesy: https://www.mailmunch.co/blog/ab-testing-got-obama-60-million/)

\section{Conclusion}

Now a days, technical skills aren't sufficiently enough for cracking real time engineering problems. Instead, it involves efficient management skills. Conflict management, conflict resolution, delegation, empowerment, time management, communication, work division, oversight, financial management, recruiting talent, strategic planning, etc. are few soft management skills that render the goals of any firms/ organizations. This is an era of democracy of data, and a good manager should trust data. Data speaks volume. Without data, any goals are based on hypothesis. Hypothesis clouds extreme pessimism, thereby causing major barrier in the smooth running of any organizations. A good management is also an art for better economy of the country as Malik rightly defines management as the transformation of resources into utility. To sum up, management, data and engineering are all strongly interrelated with each other.

\section{References}

[1].Alyoubi, A. A. (2015). E-commerce in developing countries and how to develop them during the introduction of modern systems. International conference on communication, management and information technology. Vol. 65. Pp.479-483.

[2].Assie-Lumumba and N'dri T. (2006). Higher education in Africa: crisis, reforms and transformation CODESRIA Working Paper Series.

[3].Christoph Stork, Enrico Calandro, Alison Gillwald. (2013). "Internet going mobile: internet access and use in 11 African countries", info, Vol. 15 Issue: 5, pp.34-51, https://doi.org/10.1108/info-05-2013-0026

[4].Davison, R. ,Vogel, D. , Harris, R. and Jones, N. (2000). Technology Leapfrogging in Developing Countries - An Inevitable Luxury? The Electronic Journal of Information Systems in Developing Countries. 1: 1-10

[5].Edoho, F. M. (2013). Information and communications technologies in the age of globalization: Challenges and opportunities for Africa. African Journal of Economic and Management studies. Vol. 4. Pp. 9-33.

[6].El-Fitouri, M. O. (2015). E-Commerce in Developing Countries: A Case Study on the Factors Affecting Ecommerce Adoption in Libyan Companies. International Journal of Engineering Research and Applications. Vol.5(1). pp.102-115.

[7].Ewelukwa, N. (2011). Is Africa ready for electronic commerce? European Journal of Law Reforms. Vol 13. Pp. 550576.

[8].Holm, A. E., Decreton, B., Nell, P. C. and Klopf, P. (2017). The dynamic response process to conflicting institutional demands in MNC subsidiaries: An inductive study in the Sub-Saharan African e-commerce sector. Global Strategy Journal. Vol. 7. Pp. 104-124.

[9].Kwarteng, M. A. and Pilik, M. (2016). Exploring consumers' propensity for online shopping in a developing country: A demographic perspective. International journal of entrepreneurial knowledge. Vol. 4. Pp. 90-103.

[10]. Ndonga, D. (2012). E-commerce in Africa: Challenges and Solutions. African Journal of Legal studies. Pp. $243-268$.

[11]. Molla, A. and Licker, P. S. (2005). E-Commerce adoption in developing countries: a model and instrument. Information and management. Vol. 42. Pp. 877-899.

[12]. Olivier, C. D. R. (2010). The African challenge: Internet, networking and connectivity activities in a developing 
environment, Third World Quarterly. 18:5, Pp. 883-898.

[13]. Parkes, S. (2004, April). Telecomunications-International Edition. Vol.38 Issue 4. Pp.21-25

[14]. Rahayu, R. and Day, J. (2015). Determinant factors of e-commerce adoption by SMEs in developing country: Evidence from Indonesia. World conference on technology, innovation and entrepreneurship. Vol. 195. Pp. 142150.

[15]. Selassie, B. H. (2011). Democracy and peace in the age of globalization: Old problems, new challenges for Africa. African studies review. Vol. 54. Pp. 19-31.

[16]. Terzi, N. (2011). The impact of e-commerce on international trade and employment. Procedia social and behavioral sciences. Vol. 24. Pp. 745-753.

[17]. Thomas P. B. and Subarna, K. S. (2008). Investment Flows, Economic Growth, and Corruption in African Countries: An Analysis. Journal of African Business, 9:2, Pp. 287-307.

[18]. Wresch, W. and Fraser, S. (2011). Persistent barriers to e-commerce in developing countries: A longitudinal study of efforts by Caribbean companies. Journal of global information management. Vol. 19. Pp. 30-44.

Chet Narayan Subedi completed his Bachelor in Business Studies (BBS) and Master's in Business Studies (MBS) from Tribhuvan University, Nepal in 2063 and 2066 respectively. He has 7+ years of experience in teaching in various colleges in Pokhara valley. Some colleges are Karundanidi Secondary School, Shanta Secondary School, Bhadrakali Secondary School, Prithvi Narayan Campus, Motherland Secondary School, Kalika Secondary School, etc.

His current research includes business planning, financial management, entrepreneurship for youth and efficient accounting. He is also involved in several social clubs in Pokhara valley.

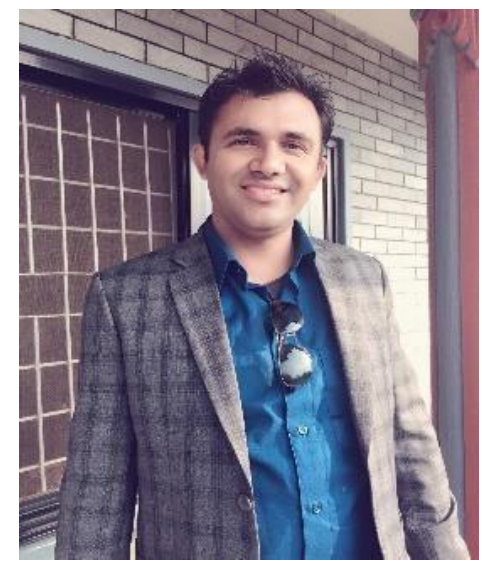

